\title{
Respon Pertumbuhan dan Hasil Bawang Merah akibat Dosis Pupuk Kalium dan Konsentrasi POC Limbah Tahu
}

\author{
(Response of Shallot Growth and Yield due to Potassium Fertilizer Dosage and \\ Concentration of Tofu Waste Organic Liquid Fertilizer)
}

\author{
Nurul Fitri Ramadhani ${ }^{1}$,Mardhiah Hayati ${ }^{1}$, Rita Hayati ${ }^{{ }^{*}}$ \\ ${ }^{1}$ Program Studi Agroteknologi, Fakultas Pertanian, Universitas Syiah Kuala
}

\begin{abstract}
Abstrak. Tujuan penelitian ini untuk mengetahui pengaruh dosis pupuk kalium dan konsentrasi pupuk organik cair limbah tahu, serta interaksi keduanya terhadap pertumbuhan dan hasil bawang merah. Penelitian ini dilaksanakan pada bulan Mei sampai Juli 2018 di Kebun Percobaan 2 dan Laboratorium Hortikultura Fakultas Pertanian Universitas Syiah Kuala. Rancangan penelitian yang digunakan adalah Rancangan Acak Kelompok pola faktorial 3 x 3 dengan 3 ulangan. Faktor yang diteliti yaitu dosis pupuk kalium yang terdiri dari 3 taraf $\left(75,100\right.$ dan $\left.125 \mathrm{~kg} \mathrm{ha}^{-1}\right)$ dan konsentrasi pupuk organik cair limbah tahu yang juga terdiri 3 dari taraf $(40,60$ dan $80 \%)$. Hasil penelitian menunjukkan pemberian dosis pupuk kalium berpengaruh sangat nyata terhadap jumlah daun pada umur 30 dan 40 HST, diameter umbi, bobot berangkasan basah, bobot basah umbi, bobot berangkasan kering, bobot kering umbi dan potensi hasil serta berpengaruh nyata terhadap tinggi tanaman pada umur $40 \mathrm{HST}$. Pertumbuhan dan hasil bawang merah terbaik dijumpai pada dosis pupuk kalium $100 \mathrm{~kg} \mathrm{ha}^{-1}$ dan diameter umbi bawang merah terbaik dijumpai pada dosis pupuk kalium $125 \mathrm{~kg} \mathrm{ha}^{-1}$. Hasil penelitian juga menunjukkan bahwa konsentrasi pupuk organik cair limbah tahu berpengaruh sangat nyata terhadap parameter diameter umbi dan potensi hasil bawang merah. Hasil bawang merah terbaik dijumpai pada konsentrasi $60 \%$. Terdapat interaksi yang sangat nyata terhadap diameter umbi dan interaksi yang nyata terhadap potensi hasil bawang merah. Diameter umbi bawang merah terbaik dijumpai pada kombinasi dosis pupuk kalium $125 \mathrm{~kg} \mathrm{ha}^{-1}$ dengan konsentrasi pupuk organik cair limbah tahu $60 \%$ dan potensi hasil bawang merah terbaik dijumpai pada kombinasi dosis pupuk kalium $100 \mathrm{~kg} \mathrm{ha}^{-1}$ dengan konsentrasi pupuk organik cair limbah tahu $60 \%$.
\end{abstract}

Kata kunci : Bawang Merah, Pupuk Organik Cair Limbah Tahu, Pupuk Kalium

Abstract. This study aims to determine the effect of potassium fertilizer dosage and the concentration of liquid organic fertilizer made by tofu waste, and the interaction of both on the growth and yield of shallot. This research was conducted from May to July 2018 in Experiment Field 2 and Horticulture Laboratory, Faculty of Agriculture, Syiah Kuala University. The design used was a Randomized Factorial Block Design 3 x 3 with 3 replications. The factors observed were potassium fertilizer dosages consisted of 3 levels (75, 100 and $125 \mathrm{~kg} \mathrm{ha}^{-1}$ ) and the concentration of liquid organic fertilizer tofu waste which also consisted of 3 levels $(40,60$ and $80 \%)$. The results was showed the application of potassium fertilizer very significantly affected plant height at age of 40 DAP, number of leaves at age 30 and 40 DAP, tuber diameter, fresh clump weight, fresh tuber weight, dry clump weight, dry tuber weight and potential yield. The best growth and yield of shallot is found at potassium fertilizer dosage of $100 \mathrm{~kg} \mathrm{ha}^{-1}$ and the largest shallot tuber diameter is found at potassium fertilizer dosage of $125 \mathrm{~kg} \mathrm{ha}^{-1}$. The result also showed that the concentration of tofu waste organic fertilizer had a significant effect on the parameters of tuber diameter and the potential yield of shallot. The best result of shallot is found at the concentration of $60 \%$. There was a real interaction with tuber diameter and the potential shallot yield. The largest diameter of shallot tuber is found in the combination of potassium fertilizer dosage of $125 \mathrm{~kg} \mathrm{ha}^{-1}$ with the concentration of liquid organic fertilizer tofu waste $60 \%$ and the highest potential shallot yield is found in the combination of potassium fertilizer dosage of $100 \mathrm{~kg} \mathrm{ha}^{-1}$ with the concentration of tofu waste organic liquid fertilizer $60 \%$.

Keywords: Potassium, Shallot, Tofu waste organic liquid fertilizer

\section{PENDAHULUAN}

\section{Latar Belakang}

Bawang merah merupakan tanaman hortikultura yang digunakan oleh masyarakat sebagai rempah dan sayuran. Di Indonesia saat tahun 2013 produksi bawang merah 
mencapai 1.010 .773 ton dan meningkat menjadi 223.227 ton pada tahun 2014 sehingga produksi bawang merah tahun 2014 adalah 1.234 .000 ton, saat tahun 2015 adalah 1,22 juta ton, dan mengalami peningkatan saat tahun 2016 sampai 1,44 juta ton. Luas panen bawang merah pada tahun 2015 adalah 122.126 ha dan pada tahun 2016 mengalami peningkatan menjadi 149.635 ha. Produktivitas bawang merah pada tahun 2015 adalah 10,06 ton $\mathrm{ha}^{-1}$, tetapi mengalami penurunan saat tahun 2016 sehingga hanya 9,67 ton ha ${ }^{-1}$ (Badan Pusat Statitik, 2016).

Produksi bawang merah dapat ditingkatkan dengan melaksanakan kegiatan budidaya yang baik seperti pada kegiatan irigasi, pemupukan, pengolahan tanah, serta pengendalian hama dan penyakit. Pemberian pupuk memberikan respon yang baik terhadap peningkatan produksi bawang merah (Istina, 2016). Pemupukan merupakan salah satu tindakan dalam meningkatkan unsur hara pada tanah agar ketersediaan nutrisi tanaman terpenuhi serta tujuan produksi tanaman dapat tercapai. Peningkatan unsur hara pada tanah dapat berasal dari penggunaan pupuk organik dan pupuk anorganik (Sitompul et al., 2017).

Pemberian pupuk kalium dan pupuk organik cair (POC) dari limbah tahu sebagai sumber pupuk anorganik dan organik merupakan upaya yang dapat dilakukan untuk meningkatkan hasil bawang merah. Martinus (2017) menyatakan dengan mengkombinasikan pupuk anorganik dengan pupuk organik pada dosis dan cara yang tepat akan mampu menghasilkan produksi tanaman yang maksimal.

Unsur kalium adalah hara esensi yang berkerja untuk memacu proses pertambahan sel dan hasil tanaman. Unsur kalium berguna untuk memacu reaksi buka dan tutup stomata dengan meningkatkan aktivitas turgor sel serta menjaga batang tanaman agar tetap berdiri tegak (Apriliani et al., 2016). Dosis kalium yang cukup pada tanaman akan meningkatkan sintesis senyawa molekul dengan berat molekul tinggi seperti protein, pati dan selulosa. Pemberian unsur kalium pada tanaman juga mampu merangsang perkembangan akar, meningkatkan ukuran, jumlah dan hasil buah serta umbi. Unsur kalium juga meningkatkan transportasi gula dan asam ke organ penyimpanan tanaman (Rosyidah, 2016).

Pemberian pupuk kalium memperlihatkan pengaruh yang nyata akan bobot umbi kering bawang merah per rumpun. Interaksi pupuk $\mathrm{N}$ menggunakan dosis $250 \mathrm{~kg} \mathrm{ha}^{-1}$ dan pupuk kalium menggunakan dosis $100 \mathrm{~kg} \mathrm{ha}^{-1}$ menghasilkan bobot kering umbi bawang merah tertinggi (Napitupulu dan Winarto, 2010). Sumarni et al. (2012) menyatakan pemberian pupuk $\mathrm{K}_{2} \mathrm{O}$ dengan dosis $120 \mathrm{~kg} \mathrm{ha}^{-1}$ menghasilkan bobot kering umbi dan bobot basah umbi bawang merah tertinggi dibandingkan dengan dosis $\mathrm{K}_{2} \mathrm{O}$ lainnya. Sinaga et al. (2016) menyatakan pemberian pupuk $\mathrm{KCl}$ dosis $75 \mathrm{~kg} \mathrm{ha}^{-1}$ dan 15 ton ha ${ }^{-1}$ pupuk kompos pada bawang merah menghasilkan diameter umbi tertinggi dibandingkan dengan tanpa pemberian pupuk KCl. Pemberian pupuk kalium menggunakan dosis $75 \mathrm{~kg} \mathrm{ha}^{-1}$ dan 7,5 ton ha $^{-1}$ pupuk kompos pada bawang merah juga menghasilkan pertumbuhan bawang merah tertinggi diumur 6 MST (Minggu Setelah Tanam) dibandingkan dengan dosis lainnya.

Pupuk organik cair adalah cairan hasil fermentasi dari bahan organik seperti sisa tanaman, limbah agroindustri, kotoran hewan dan manusia yang mampu menjadi sumber unsur hara yang dibutuhkan oleh tanaman (Hidayati, 2013). Limbah cair tahu memiliki potensi yang besar untuk dijadikan sebagai POC. Limbah cair tahu yang difermentasi mengandung kadar nitrogen sebesar 732 ppm, kadar phospor sebesar 840,6 ppm dan kadar kalium sebesar 7189,8 ppm (Makiyah, 2013). Pemberian limbah cair tahu pada konsentrasi $62 \mathrm{ml}$ per tanaman memperlihatkan pengaruh yang nyata pada berat kering biji kacang hijau (Hikmah, 2016). Menurut Nurman et al. (2017) POC limbah cair tahu yang diberikan pada konsentrasi $75 \%$ mampu menaikkan jumlah daun, jumlah umbi, berat basah umbi dibandingkan dengan tanpa pemberian limbah cair tahu pada bawang merah. Pakcoy yang 
diberikan limbah tahu mampu meningkatkan pertumbuhan tanaman secara nyata pada indikator berat basah, pertambahan tinggi dan daun pada pakcoy. Pemberian POC limbah cair tahu pada konsentrasi 25-50\% merupakan konsentrasi yang baik untuk pertumbuhan dan produksi tanaman pakcoy (Amin et al., 2017).

Berdasarkan uraian di atas, belum diketahui dosis pupuk kalium dan konsentrasi pupuk organik cair limbah tahu yang sesuai untuk menaikkan hasil bawang merah. Diharapkan dengan mengkombinasikan pupuk kalium dengan POC limbah tahu mampu menaikkan produksi bawang merah. Oleh sebab itu perlu dilakukan penelitian untuk menemukan kombinasi dosis pupuk kalium dan konsentrasi POC limbah tahu yang tepat.

\section{Hipotesis}

1. Dosis pupuk kalium berpengaruh terhadap pertumbuhan dan hasil tanaman bawang merah.

2. Konsentrasi pupuk organik cair limbah tahu berpengaruh terhadap pertumbuhan dan hasil tanaman bawang merah.

3. Adanya interaksi antara kedua faktor terhadap pertmbuhan dan hasil tanaman bawang

\section{METODE PENELITIAN}

\section{Tempat dan Waktu Penelitian}

Penelitian dikerjakan dari bulam Mei ampai Juli 2018, di Kebun Percobaan 2 dan Laboratorium Hortikultura Fakultas Pertanian Universitas Syiah Kuala, Banda Aceh.

\section{Alat dan Bahan Penelitian}

Alat yang dipakai adalah meteran, cangkul, garu, tali rafia, gembor, ember, gelas ukur, pH meter, gayung, jangka sorong, timbangan digital, timbangan $100 \mathrm{~kg}$,alat tulis dan papan label. Bahan yang dipakai adalah umbi bawang merah varietas Brebes sebanyak 6 kg umbi, $\mathrm{EM}_{4} 2 \mathrm{~L}$, air kelapa $4 \mathrm{~L}, 1 \mathrm{~kg}$ gula pasir, $220 \mathrm{~L}$ limbah cair tahu, 0,972 kg pupuk SP-36, 1,215 kg pupuk Urea, dan 0,486 kg pupuk KCl.

\section{Rancangan Percobaan}

Penelitian ini memakai Rancangan Acak Kelompok (RAK) factorial 3 x 3 dengan 3 ulangan. Setiap satuan uji terdiri dari 5 tanaman sampel. Ada dua factor yang diteliti yaitu pengaruh dosis pupuk kalium dan konsentrasi pupuk organik cair limbah tahu. Faktor kesatu dosis pupuk kalium (K) yang terdisi dari 3 taraf yaitu 75, 100 dan $125 \mathrm{~kg} \mathrm{ha}^{-}$ ${ }^{1}$ dan konsentrasi POC limbah tahu (T) sebagai factor kedua yang juga terdiri dari tiga taraf yaitu 40, 60 dan 80\%. Susunan perlakuan dosis pupuk kalium dan konsentrasi pupuk organik cair limbah tahu pada bawang merah dapat dilihat pada Tabel 1.

Tabel 1. Susunan kombinasi perlakuan dosis pupuk kalium dan konsentrasi pupuk organik cair limbah tahu pada bawang merah.

\begin{tabular}{cccc}
\hline & & \multicolumn{2}{c}{ Perlakuan } \\
\cline { 3 - 4 } No. & $\begin{array}{c}\text { Kombinasi } \\
\text { Perlakuan }\end{array}$ & $\begin{array}{c}\text { Dosis Pupuk Kalium } \\
\left(\mathrm{kg} \mathrm{ha}^{-1}\right)\end{array}$ & $\begin{array}{c}\text { Konsentrasi POC Limbah } \\
\text { Tahu (\%) }\end{array}$ \\
\hline 1 & $\mathrm{~K}_{1} \mathrm{~T}_{1}$ & 75 & 40 \\
2 & $\mathrm{~K}_{1} \mathrm{~T}_{2}$ & 75 & 60 \\
3 & $\mathrm{~K}_{1} \mathrm{~T}_{3}$ & 75 & 80 \\
4 & $\mathrm{~K}_{2} \mathrm{~T}_{1}$ & 100 & 40 \\
5 & $\mathrm{~K}_{2} \mathrm{~T}_{2}$ & 100 & 60 \\
6 & $\mathrm{~K}_{2} \mathrm{~T}_{3}$ & 100 & 80 \\
7 & $\mathrm{~K}_{3} \mathrm{~T}_{1}$ & 125 & 40 \\
8 & $\mathrm{~K}_{3} \mathrm{~T}_{2}$ & 125 & 60 \\
9 & $\mathrm{~K}_{3} \mathrm{~T}_{3}$ & 125 & 80 \\
\hline
\end{tabular}


Setelah data didapat, selanjutnya dianalisis secara statistik dengan ANOVA (analysis of variance) untuk melihat pengaruh perlakuan. Bila perlakuan berpengaruh nyata, akan dilakukan analisis lanjut menggunakan uji BNJ pada taraf 5\%.

\section{Pelaksanaan Penelitian}

Tanah dibersihkan terlebih dahulu dari gulma. Selanjutnya dibuat bedengan ukuran $150 \mathrm{~cm}$ x $120 \mathrm{~cm}$ sebanyak 27 bedengan, antar bedengan berjarak $40 \mathrm{~cm}$ dan antar blok berjarak $40 \mathrm{~cm}$ sebagai drainase. Umbi yang sehat sepertiga bagian atasnya dipotong untuk memacu tumbuhnya tunas. Kemudian umbi ditanam menggunakan jarak 20 x $20 \mathrm{~cm}$. Pupuk SP-36 $\left(100 \mathrm{~kg} \mathrm{ha}^{-1}\right)$, pupuk urea $\left(150 \mathrm{~kg} \mathrm{ha}^{-1}\right)$ dan pupuk $\mathrm{KCl}$ sesuai dosis perlakuan $\left(75,100\right.$ dan $\left.125 \mathrm{~kg} \mathrm{ha}^{-1}\right)$ diberikan saat tanam secara larikan pada sore hari. Pupuk cair limbah tahu yang sudah difermentasi diaplikasikan sesuai dengan konsentrasi perlakuan yaitu 40, 60 dan $80 \%$ seminggu sekali dimulai pada umur bawang merah 21, 28, 35 dan 42 HST sebanyak 3 Liter per bedeng.

Pemeliharaan tanaman bawang merah meliputi pendirusan, penyulaman, penyiangan, serta pengendalian organisme pengganggu tanaman (OPT). Pengendalian OPT dilaksanakan saat gejala serangan telah muncul dengan penyemprotan fungisida berbahan aktif Mangkozep sebanyak $2 \mathrm{~g} \mathrm{~L}^{-1}$. Panen bawang merah dilakukan pada saat bawang merah berumur 65 HST. Kriteria bawang merah yang sudah siap panen yaitu sekitar 70$80 \%$ daun bawang merah dari jumlah yang ditanam sudah mulai layu dan menguning, batang mulai layu, beberapa umbi terlihat muncul permukaan tanah, petala umbi telah berisi dan bewarna merah.

\section{Parameter Pengamatan}

Adapun indicator yang diamati adalah tinggi tanaman dan jumlah daun saat umur 10, 20, 30 dan 40 HST. Tinggi tanaman diukur dari mulai pangkal batang yang tandai sampai ujung daun tertinggi, dan daun bawang merah yang dihitung adalah daun yang segar dan bewarna hijau. Apabila daun telah layu dan menguning maka daun tidak dihitung lagi. Pengamatan jumlah anakan bawang merah dilakukan dengan cara menghitung anakan yang muncul di permukaan tanah pada umur 30 dan 40 HST. Pengamatan jumlah umbi bawang merah per rumpun dihitung setelah panen. Bobot berangkasan basah dan bobot basah umbi ditimbang setelah panen menggunakan timbangan digital. Bobot berangkasan kering dan bobot kering umbi ditimbang menggunakan timbangan digital setelah dikeringanginkan selama 10 hari. Potensi hasil bawang merah dihitung dengan menggunakan data rata-rata berat kering umbi bawang merah menggunakan formula berikut ini:

$$
\text { Potensi hasil }\left(\text { ton } \mathrm{ha}^{-1}\right)=\frac{\text { Luas lahan } 1 \mathrm{ha}-20 \%}{\text { Luas plot netto }} \times \text { Hasil plot netto }
$$

\section{HASIL DAN PEMBAHASAN}

\section{Hasil Penelitian \\ Pengaruh Dosis Pupuk Kalium terhadap Pertumbuhan dan Hasil Tanaman Bawang Merah}

Hasil uji $\mathrm{F}$ menunjukkan bahwa dosis pupuk kalium berpengaruh sangat nyata terhadap jumlah daun bawang merah saat umur 30 dan 40 HST, bobot berangkasan basah, bobot basah umbi, bobot berangkasan kering, bobot kering umbi, diameter umbi, dan potensi hasil serta berpengaruh nyata terhadap tinggi tanaman saat umur $40 \mathrm{HST}$, namun berpengaruh tidak nyata pada tinggi tanaman umur 10, 20 dan 30 HST, jumlah daun umur 10 dan 20 HST, jumlah anakan per rumpun umur 30 dan 40 HST serta jumlah umbi per 
rumpun. Rata-rata pertumbuhan dan hasil bawang merah akibat dosis pupuk kalium bisa dilihat pada Tabel 2.

Tabel 2. Rata-rata pertumbuhan dan hasil bawang merah akibat dosis pupuk kalium

\begin{tabular}{|c|c|c|c|c|c|}
\hline \multirow{2}{*}{\multicolumn{2}{|c|}{ Parameter yang diamati }} & \multicolumn{3}{|c|}{ Dosis Pupuk Kalium $\left(\mathrm{kg} \mathrm{ha}^{-1}\right)$} & \multirow{2}{*}{$\mathrm{BNJ}_{0,05}$} \\
\hline & & \multirow{2}{*}{$\begin{array}{c}75 \\
16,28\end{array}$} & \multirow{2}{*}{$\begin{array}{c}100 \\
16,62\end{array}$} & \multirow{2}{*}{$\begin{array}{c}125 \\
17,22\end{array}$} & \\
\hline Tinggi tanaman $(\mathrm{cm})$ & $10 \mathrm{HST}$ & & & & - \\
\hline & $20 \mathrm{HST}$ & 22,30 & 23,75 & 23,78 & - \\
\hline & $30 \mathrm{HST}$ & 24,08 & 25,77 & 25,88 & - \\
\hline & $40 \mathrm{HST}$ & $25,07 \mathrm{a}$ & $27,32 \mathrm{~b}$ & $27,43 \mathrm{~b}$ & 2,22 \\
\hline \multirow[t]{4}{*}{ Jumlah Daun (helai) } & $10 \mathrm{HST}$ & 10,13 & 10,88 & 11,22 & - \\
\hline & $20 \mathrm{HST}$ & 13,84 & 15,02 & 15,55 & - \\
\hline & $30 \mathrm{HST}$ & $13,95 \mathrm{a}$ & $16,77 \mathrm{~b}$ & $17,75 \mathrm{~b}$ & 2,32 \\
\hline & $40 \mathrm{HST}$ & $12,44 \mathrm{a}$ & $14,73 \mathrm{~b}$ & $15,66 \mathrm{~b}$ & 2,15 \\
\hline \multirow[t]{2}{*}{ Jumlah Anakan (anakan) } & $30 \mathrm{HST}$ & 3,13 & 3,73 & 3,93 & - \\
\hline & $40 \mathrm{HST}$ & 3,40 & 3,95 & 4,15 & - \\
\hline \multicolumn{2}{|l|}{ Jumlah Umbi (umbi) } & 5,02 & 5,44 & 5,57 & - \\
\hline \multicolumn{2}{|c|}{ Bobot Berangkasan basah (g) } & $17,02 \mathrm{a}$ & $25,27 b$ & $28,56 \mathrm{~b}$ & 7,85 \\
\hline \multicolumn{2}{|c|}{ Bobot Basah Umbi (g) } & $15,38 \mathrm{a}$ & $21,87 \mathrm{~b}$ & $24,36 \mathrm{~b}$ & 6,20 \\
\hline \multicolumn{2}{|c|}{ Bobot Berangkasan Kering (g) } & $13,18 \mathrm{a}$ & $18,60 \mathrm{ab}$ & $21,60 \mathrm{~b}$ & 5,56 \\
\hline \multicolumn{2}{|c|}{ Bobot Kering Umbi (g) } & $12,66 \mathrm{a}$ & $18,05 \mathrm{~b}$ & $21,00 \mathrm{~b}$ & 5,33 \\
\hline \multicolumn{2}{|l|}{ Diameter Umbi (mm) } & $18,20 \mathrm{a}$ & $23,25 \mathrm{~b}$ & $26,31 \mathrm{c}$ & 1,39 \\
\hline \multicolumn{2}{|l|}{ Potensi Hasil (ton ha ${ }^{-1}$ ) } & $2,78 \mathrm{a}$ & $3,05 \mathrm{~b}$ & $3,07 \mathrm{~b}$ & 0,12 \\
\hline
\end{tabular}

Keterangan : Angka yang diikuti oleh huruf yang sama pada baris yang sama berbeda tidak nyata pada taraf $5 \%\left(\mathrm{BNJ}_{0,05}\right)$

Pengaruh Konsentrasi POC Limbah Tahu terhadap Pertumbuhan dan Hasil Tanaman Bawang Merah

Tabel 3. Rata-rata pertumbuhan dan hasil bawang merah akibat konsentrasi POC limbah tahu

\begin{tabular}{|c|c|c|c|c|c|}
\hline \multicolumn{2}{|c|}{ Parameter yang diamati } & \multicolumn{3}{|c|}{ Konsentrasi POC Limbah Tahu (\%) } & \multirow[t]{2}{*}{$\mathrm{BNJ}_{0,05}$} \\
\hline & & 40 & 60 & 80 & \\
\hline \multirow[t]{4}{*}{ Tinggi tanaman $(\mathrm{cm})$} & $10 \mathrm{HST}$ & 16,63 & 17,03 & 16,46 & - \\
\hline & 20 HST & 22,84 & 23,59 & 23,41 & - \\
\hline & $30 \mathrm{HST}$ & 24,14 & 25,98 & 25,62 & - \\
\hline & 40 HST & 25,60 & 27,30 & 26,92 & - \\
\hline \multirow[t]{4}{*}{ Jumlah Daun (helai) } & $10 \mathrm{HST}$ & 10,53 & 11,08 & 10,62 & - \\
\hline & 20 HST & 14,62 & 15,02 & 14,77 & - \\
\hline & $30 \mathrm{HST}$ & 16,02 & 16,24 & 16,22 & - \\
\hline & $40 \mathrm{HST}$ & 14,31 & 14,55 & 13,97 & - \\
\hline \multicolumn{2}{|c|}{ Jumlah Anakan (anakan)30 HST } & 3,15 & 3,73 & 3,57 & - \\
\hline & $40 \mathrm{HST}$ & 4,35 & 4,28 & 4,28 & - \\
\hline \multicolumn{2}{|c|}{ Jumlah Umbi (umbi) } & 5,13 & 5,91 & 5,48 & - \\
\hline \multicolumn{2}{|c|}{ Bobot Berangkasan basah (g) } & 22,23 & 25,13 & 23,49 & - \\
\hline \multicolumn{2}{|c|}{ Bobot Basah Umbi (g) } & 19,54 & 21,74 & 20,33 & - \\
\hline \multicolumn{2}{|c|}{ Bobot Berangkasan Kering (g) } & 16,44 & 19,41 & 17,53 & - \\
\hline \multicolumn{2}{|c|}{ Bobot Kering Umbi (g) } & 15,98 & 18,67 & 17,06 & - \\
\hline \multicolumn{2}{|l|}{ Diameter Umbi (mm) } & $18,23 \mathrm{a}$ & $25,54 \mathrm{c}$ & $24,00 \mathrm{~b}$ & 1,39 \\
\hline \multicolumn{2}{|l|}{ Potensi Hasil (ton ha ${ }^{-1}$ ) } & $2,76 \mathrm{a}$ & $3,08 \mathrm{~b}$ & $3,06 \mathrm{~b}$ & 0,12 \\
\hline
\end{tabular}

Keterangan : Angka yang diikuti oleh huruf yang sama pada baris yang sama berbeda tidak nyata pada taraf $5 \%\left(\mathrm{BNJ}_{0,05}\right)$ 
Hasil uji $\mathrm{F}$ menunjukkan bahwa konsentrasi POC limbah tahu berpengaruh sangat nyata terhadap diameter umbi dan potensi hasil bawang merah, namun berpengaruh tidak nyata terhadap tinggi tanaman dan jumlah daun saat umur 10, 20, 30 dan 40 HST, jumlah anakan per rumpun, jumlah umbi per rumpun, bobot berangkasan basah, bobot basah umbi, bobot berangkasan kering dan bobot kering umbi bawang merah. Rata-rata pertumbuhan dan hasil bawang merah akibat konsentrasi POC limbah tahu bisa dilihat pada Tabel 3.

\section{Pengaruh Interaksi antara Dosis Pupuk Kalium dan Konsentrasi POC Limbah Tahu terhadap Pertumbuhan dan Hasil Tanaman Bawang Merah}

Hasil uji F (Lampiran 1) menunjukkan bahwa terdapat interaksi yang sangat nyata antara dosis pupuk kalium dengan konsentrasi POC limbah tahu terhadap parameter diameter umbi dan interaksi yang nyata terhadap parameter potensi hasil bawang merah. Diameter umbi bawang merah terbaik dijumpai pada kombinasi dosis pupuk kalium $125 \mathrm{~kg}$ $\mathrm{ha}^{-1}$ dengan konsentrasi POC limbah tahu $60 \%$ dan potensi hasil bawang merah terbaik dijumpai pada kombinasi dosis pupuk kalium $100 \mathrm{~kg} \mathrm{ha}^{-1}$ dengan konsentrasi POC limbah tahu 60\%. Interaksi antara perlakuan dosis pupuk kalium dengan konsentrasi POC limbah tahu terhadap diameter umbi dan potensi bawang merah bisa dilihat pada Tabel 5 .

Tabel 5. Interaksi antara perlakuan dosis pupuk kalium dengan konsentrasi POC limbah tahu terhadap diameter umbi dan potensi hasil bawang merah

\begin{tabular}{|c|c|c|c|c|c|}
\hline \multirow{2}{*}{$\begin{array}{c}\text { Parameter yang } \\
\text { diamati }\end{array}$} & \multirow{2}{*}{$\begin{array}{l}\text { Dosis Pupuk } \\
\text { Kalium (kg ha }_{\left.{ }_{1}\right)}\end{array}$} & \multicolumn{3}{|c|}{ Konsentrasi POC Limbah Tahu (\%) } & \multirow[t]{2}{*}{$\mathrm{BNJ}_{5 \%}$} \\
\hline & & 40 & 60 & 80 & \\
\hline \multirow{3}{*}{$\begin{array}{l}\text { Diameter Umbi } \\
\qquad(\mathrm{mm})\end{array}$} & 75 & $16,97 \mathrm{Aa}$ & $19,59 \mathrm{Ba}$ & $18,05 \mathrm{Aa}$ & \multirow{3}{*}{1,39} \\
\hline & 100 & $18,29 \mathrm{Aab}$ & $26,97 \mathrm{Cb}$ & $24,49 \mathrm{Bb}$ & \\
\hline & 125 & $19,42 \mathrm{Ab}$ & $30,05 \mathrm{Bc}$ & $29,47 \mathrm{Bc}$ & \\
\hline \multirow{3}{*}{$\begin{array}{l}\text { Potensi Hasil (kg } \\
\left.\mathrm{ha}^{-1}\right)\end{array}$} & 75 & $2,73 \mathrm{Aa}$ & $2,84 \mathrm{Ba}$ & $2,71 \mathrm{Aa}$ & \multirow{3}{*}{0,12} \\
\hline & 100 & $2,84 \mathrm{Aa}$ & $3,16 \mathrm{Bb}$ & $3,24 \mathrm{Bb}$ & \\
\hline & 125 & $2,77 \mathrm{Aa}$ & $3,14 \mathrm{Bb}$ & $3,26 \mathrm{Bb}$ & \\
\hline
\end{tabular}

Keterangan : Angka yang diikuti oleh huruf yang sama ( huruf kapital dilihat menurut baris dan huruf kecil menurut kolom) berbeda tidak nyata pada taraf 5\% (Uji $\mathrm{BNJ}{ }_{0,05}$ ) pada masing-masing peubah.

\section{Pembahasan}

\section{Pengaruh Dosis Pupuk Kalium terhadap Pertumbuhan dan Hasil Tanaman Bawang Merah}

Hasil penelitian menunjukkan pertumbuhan tanaman bawang merah terbaik dijumpai pada dosis pupuk kalium $100 \mathrm{~kg} \mathrm{ha}^{-1}$ yang tidak berbeda nyata dengan dosis pupuk kalium $125 \mathrm{~kg} \mathrm{ha}^{-1}$. Perihal ini diduga karena pemberian pupuk kalium $100 \mathrm{~kg} \mathrm{ha}^{-1}$ pada bawang merah sudah mampu memacu proses metabolisme tanaman menjadi optimum terutama dalam pembentukan sel-sel baru pada masa pertumbuhan bawang merah. Sesuai dengan penelitian Uke et al. (2015) yang juga mendapatkan nilai tinggi tanaman pada umur 45 HST, bobot berangkasan basah dan bobot berangkasan kering bawang merah tertinggi pada dosis pupuk kalium $100 \mathrm{~kg} \mathrm{ha}^{-1}$.

Bobot basah umbi, bobot kering umbi dan potensi hasil tertinggi juga terlihat pada dosis pupuk Kalium $100 \mathrm{~kg} \mathrm{ha}^{-1}$ yang berbeda tidak nyata dengan dosis pupuk kalium 125 $\mathrm{kg} \mathrm{ha}^{-1}$. Hal ini sesuai atas penelitian Ernawati (2015) yang juga mendapatkan hasil bawang merah tertinggi pada dosis pupuk kalium $100 \mathrm{~kg} \mathrm{ha}^{-1}$. Perihal ini diduga karena pemberian pupuk kalium pada dosis $100 \mathrm{~kg} \mathrm{ha}^{-1}$ mengandung zat hara yang cukup untuk menaikkan hasil umbi bawang merah. Kalium yang terkandung di dalam tanah berfungsi untuk meningkatkan berbagai enzim pertumbuhan, metabolisme karbohidrat, metabolisme 
nitrogen, translokasi pati dan sintesis protein. Unsur kalium yang cukup dan seimbang di dalam tanah akan memberikan dampak yang baik terhadap tranlokasi asimilat dari daun ke organ penyimpanan tanaman, pada bawang merah organ penyimpanannya adalah umbi (Hanafiah, 2010).

Diameter umbi bawang merah tertinggi dijumpai pada dosis pupuk kalium $125 \mathrm{~kg}$ $\mathrm{ha}^{-1}$ yang berbeda nyata dengan dosis Kalium 75 dan $100 \mathrm{~kg} \mathrm{ha}^{-1}$. perihal ini diduga dengan pemberian pupuk kalium pada dosis yang tinggi mampu memperbaiki ukuran umbi bawang merah. Sejalan dengan penelitian Napitupulu dan Winarto (2010) yang juga mendapatkan nilai diameter umbi bawang merah tertinggi pada dosis pupuk kalium $125 \mathrm{~kg}$ $\mathrm{ha}^{-1}$ dibanding dengan dosis lainnya. Munawar (2011) menyatakan unsur kalium berperan dalam proses fotosintesis yang membentuk senyawa organik yang kemudian diangkut ke organ reproduktif seperti buah, biji dan umbi sehingga warna, rasa, ukuran dan kulit buah akan menjadi lebih baik.

\section{Pengaruh Konsentrasi POC Limbah Tahu terhadap Pertumbuhan dan Hasil Tanaman Bawang Merah}

Hasil penelitian memperlihatkan bahwa konsentrasi POC limbah tahu terbaik atas diameter umbi dan potensi hasil dijumpai pada konsentrasi $60 \%$ yang tidak berbeda nyata dengan konsentrasi POC limbah tahu 80\%, namun berbeda nyata dengan konsentrasi POC limbah tahu 40\%. Hal ini diduga karena konsentrasi POC limbah tahu 60\% sudah mampu memenuhi kebutuhan unsur hara untuk proses pembentukan umbi. Pemberian POC limbah tahu konsentrasi $60 \%$ pada bawang merah juga telah mampu mempengaruhi sifat fisik, biologi dan kimia tanah dengan kandungan bahan organiknya, sehingga membentuk porositas tanah yang baik untuk pembesaran umbi bawang merah.

Dalam POC limbah tahu tersedia hara makro nitrogen, phospor, kalium dan beberapa hara mikro yang mampu memacu proses pembentukan umbi bawang merah. Kusumawati et al. (2015) menyatakan kadar nitrogen, phospor dan kalium pada limbah cair tahu mecapai 43,37; 114,36 dan $223 \mathrm{mg} \mathrm{L}^{-1}$. Terpenuhinya kebutuhan unsur hara pada tanaman akan meningkatkan proses metabolisme tanaman sehingga membentuk karbohidrat yang digunakan pada proses pembelahan dan pembesaran sel (Nurman et al., 2017).

\section{Pengaruh Interaksi antara Dosis Pupuk Kalium dan Konsentrasi POC Limbah Tahu terhadap Pertumbuhan dan Hasil Tanaman Bawang Merah}

Diameter umbi bawang merah terbaik dijumpai pada kombinasi dosis pupuk kalium $125 \mathrm{~kg} \mathrm{ha}^{-1}$ dengan konsentrasi POC limbah tahu $60 \%$ yang memberikan hasil rata-rata diameter umbi bawang merah $30,05 \mathrm{~mm}$. Potensi hasil bawang merah terbaik dijumpai pada kombinasi terbaik antara dosis pupuk kalium $100 \mathrm{~kg} \mathrm{ha}^{-1}$ dengan konsentrasi POC limbah tahu $60 \%$ yang memberikan rata-rata potensi hasil 3,16 ton ha ${ }^{-1}$. Hal ini diduga karena POC limbah tahu yang berbentuk larutan sehingga mempercepat reaksi dan ketersediaan kalium di dalam tanah. Selain itu kandungan unsur hara makro dan mikro pada POC limbah tahu telah mampu menyediakan hara yang seimbang dan meningkatkan kapasitas tukar kation (KTK) didalam tanah. Sesuai dengan pernyataan Novizan (2005) bahwa penambahan bahan organik pada bawang merah selain meningkatkan kandungan hara juga mampu meningkatkan KTK tanah yang akan mempengaruhi pertumbuhan bawang merah. Meningkatnya KTK berfungsi agar penyerapan unsur hara oleh tanaman dapat berjalan secara maksimal.

Dosis pupuk kalium $100 \mathrm{~kg} \mathrm{ha}^{-1}$ telah mampu mencukupi kebutuhan hara terhadap potensi hasil dan dosis pupuk kalium $125 \mathrm{~kg} \mathrm{ha}^{-1}$ mampu menghasilkan diameter umbi 
bawang merah tertinggi yang dikombinasikan dengan POC limbah tahu 60\%. Hal ini diduga berkaitan dengan keseimbangan unsur hara didalam tanah, dengan terpenuhinya unsur hara pada tanaman maka metabolisme tumbuhan akan meningkat sehingga hasil tanaman menjadi optimal. Menurut Sutrisna et al. (2003) unsur hara yang seimbang pada tanah terutama kalium akan berguna dalam proses pembentukan karbo dan protein yang akan mendukung proses pembesaran umbi.

\section{KESIMPULAN DAN SARAN}

Hasil penelitian memperlihatkan bahwa pertumbuhan dan hasil bawang merah terbaik diperoleh pada dosis pupuk kalium $100 \mathrm{~kg} \mathrm{ha}^{-1}$ dan diameter umbi bawang merah terbaik di jumpai pada dosis pupuk kalium $125 \mathrm{~kg} \mathrm{ha}^{-1}$. Pertumbuhan dan hasil bawang merah terbaik diperoleh pada konsentrasi POC limbah tahu 60\%. Terdapat interaksi sangat nyata terhadap diameter umbi dan interaksi yang nyata terhadap potensi hasil bawang merah. Diameter umbi bawang merah terbaik diperoleh pada kombinasi dosis pupuk kalium $125 \mathrm{~kg} \mathrm{ha}^{-1}$ dengan konsentrasi POC limbah tahu $60 \%$ dan potensi hasil bawang merah terbaik diperoleh pada kombinasi dosis kalium $100 \mathrm{~kg} \mathrm{ha}^{-1}$ dengan konsentrasi POC limbah tahu $60 \%$.

Perlu dilakukan penelitian lanjutan dengan pemberian POC limbah tahu yang dimulai dari umur bawang merah 7 HST agar POC limbah tahu memberikan pengaruh terhadap masa vegetative bawang merah sehingga pertumbuhan bawang merah menjadi lebih optimum.

\section{DAFTAR PUSTAKA}

Amin, A.A., A.E. Yulia dan Nurbaiti. 2017. Pemanfaatan limbah cair tahu untuk pertumbuhan dan produksi tanaman pakcoy (Brassica rapa L.). Jurnal Online Mahasiswa Bidang Pertanian. 4(2):1-11.

Apriliani, I.N., S. Heddy dan N.E. Suminarti. 2016. Pengaruh Kalium pada pertumbuhan dan hasil dua varietas tanaman ubi jalar (Ipomea batatas L.). Jurnal Produksi Tanaman. 4(4):264-270.

Badan Pusat Statistik. 2016. Produksi Bawang Merah. http://www.Bps.Go.Id>Brs>View [10 Februari 2018].

Ernawati, L. 2015. Pengaruh bobot bibit dan dosis pupuk Kalium terhadap serapan K, pertumbuhan dan hasil tanaman bawang merah (Allium ascalonicum L.) varietas bima. Agroswagati. 3(2):332-343.

Hanafiah, K. A. 2010. Dasar-Dasar Ilmu Tanah. Rajawali Press. Jakarta.

Hidayati, E. 2013. Kandungan Fosfor, C/N, dan pH Pupuk Cair Hasil Fermentasi Kotoran Berbagai Ternak dengan Starter Stardec. Skripsi. Fakultas Pendidikan Matematika dan Ilmu Pengetahuan Alam. PGRI Semarang, Semarang.

Hikmah, N. 2016. Pengaruh pemberian limbah tahu terhadap pertumbuhan dan hasil tanaman kacang hijau (Vigna radiata L.). Agrotropika Hayati. 3(3):46-52.

Istina, I.N. 2016. Peningkatan produksi bawang merah melalui teknik pemupukan NPK. Jurnal Agro. 3(1): 36-42.

Kusumawati, K., S. Muhartini dan R. Rogomulyo. 2015. Pengaruh konsentrasi dan frekuensi pemberian limbah tahu terhadap pertumbuhan dan hasil bayam (Amaranthus tricolor L.) pada media pasir pantai. Vegetalika. 4(2):48-62.

Makiyah, M. 2013. Analisis Kadar N, P dan K pada Pupuk Cair Limbah Tahu dengan Penambahan Tanaman Matahari Meksiko (Thitonia diversi volia). Skripsi. Fakultas Matematika dan Ilmu Pengetahuan Alam. Universitas Negeri Semarang, Semarang. 
Martinus, E., H. Hanum dan A. Lubis. 2017. Pengaruh pemberian pupuk kandang kerbau dan dosis pupuk anorganik terhadap hara $\mathrm{N}, \mathrm{P}, \mathrm{K}$ tanah, pertumbuhan dan produksi bawang merah (Allium ascalonicum L.). Jurnal Agroekoteknologi. 5(2):265- 270.

Munawar, A. 2011. Kesuburan Tanah dan Nutrisi Tanaman. IPB Press. Bogor.

Napitupulu, D. dan L. Winarto. 2010. Pengaruh pemberian pupuk N dan K terhadap pertumbuhan dan produksi bawang merah. Jurnal Hortikultura. 20(1):27-25.

Novizan. 2005. Petunjuk Pemupukan yang Efektif. Agro Media Pustaka. Jakarta.

Nurman., E. Zuhry dan I.R. Dini. 2017. Pemanfaatan zpt air kelapa dan POC limbah cair tahu untuk pertumbuhan dan produksi bawang merah (Allium ascalonicum L.). Jurnal Onine Mahasiswa Bidang Pertanian. 4(2):1-15.

Peraturan Pemerintah Pertanian. No 70/permentan/Sr.140/10/2011. Tentang Pupuk Organik, Pupuk Hayati dan Tanah.

Rosyidah, A. 2016. Respon Pemberian Pupuk Kalium Terhadap Ketahanan Penyakit Layu Bakteri dan Karakter Agronomi pada Tomat (Solanum lycopersicum L.). Seminar Nasional Hasil Penelitian. Universitas Islam Malang, Malang.

Sinaga, S.F., T. Simanungkalit dan Y. Hasanah. 2016. Respons pertumbuhan bawang merah (Allium ascalonicum L.) terhadap pemberian kompos sampah kota dan pupuk K. Jurnal Agroteknologi. 4(3):2181-2187.

Sitompul, G.S.S., H. Yetti dan Murniati. 2017. Pengaruh pemberian pupuk kandang dan $\mathrm{KCl}$ terhadap pertumbuhan dan produksi tanaman bawang merah (Allium ascalonicum L.). Jurnal Online Mahasiswa Bidang Pertanian. 4(1):1-12.

Sumarni, N., R. Rosliani., R.S. Basuki dan Y. Hilman. 2012. Pengaruh varietas, status Ktanah, dan dosis pupuk Kalium terhadap pertumbuhan, hasil umbi, dan serapan hara K tanaman bawang merah. Jurnal Hortikultura. 22:(3)233-241.

Sutrisna, N., S. Suwalan dan Ishaq. 2003. Uji kelayakan teknis dan finansial penggunaan pupuk NPK anorganik pada tanaman kentang dataran tinggi jawa barat. Jurnal Hortikultura. 13(1):67-75.

Uke, K.H.Y., H. Barus dan I.S. Madauna. 2015. Pengaruh ukuran umbi dan dosis Kalium terhadap pertumbuhan dan hasil produksi bawang merah (Allium ascalonicum L.) varietas lembah palu. Jurnal Agrotekbis. 3(6):655-661 